\title{
Properties of Green Particleboard Manufactured from Coconut Fiber Using a Potato Starch Based Adhesive
}

\author{
Amina Adedoja Owodunni, ${ }^{a}$ Junidah Lamaming, ${ }^{a}$ Rokiah Hashim,,${ }^{\mathrm{a}, *}$ Owolabi Folahan \\ Abdulwahab Taiwo, ${ }^{\mathrm{a}, \mathrm{b}}$ Mohd Hazwan Hussin, ${ }^{\mathrm{c}}$ Mohamad Haafiz Mohamad Kassim, ${ }^{\mathrm{a}}$ \\ Yazmin Bustami, ${ }^{\mathrm{d}}$ Othman Sulaiman, ${ }^{\mathrm{a}}$ Mohd Hazim Mohamad Amini, ${ }^{\mathrm{e}}$ and Salim \\ Hiziroglu ${ }^{\mathrm{f}}$
}

\begin{abstract}
Particleboards were manufactured using coconut fibers (Cocos nucifera). The panels were made using different green adhesives, i.e., native potato starch, citric acid, and glutardialdehyde modified potato starch, that were applied at $10 \%, 12 \%$, and $15 \%$ based on oven-dry particle weight for each green adhesive type. The properties of the panels were determined according to the Japanese industrial standard. The results showed that the panels that were bonded with the $15 \%$ citric acid-modified starch green adhesive yielded the best mechanical properties (the modulus of elasticity, modulus of rupture, and internal bonding strength). The modified potato starch had potential as a green adhesive used for the production of particleboards from coconut fibers.
\end{abstract}

Keywords: Mechanical properties; Physical properties; Coconut fiber; Potato starch; Citric acid; Glutardialdehyde

Contact information: a: Division of Bioresource, Paper and Coatings Technology, School of Industrial Technology, Universiti Sains Malaysia, Penang 11800 Malaysia; b: Pulp and Paper Division, Federal Institute of Industrial Research Oshodi Lagos, Nigeria; c: School of Chemical Sciences, Universiti Sains Malaysia, Penang 11800 Malaysia; d: School of Biological Sciences, Universiti Sains Malaysia, Penang 11800 Malaysia; e: Faculty of Engineering and Technology, Universiti Malaysia Kelantan, Malaysia; $f$ : Department of Natural Resource Ecology and Management, Oklahoma State University Stillwater, OK 74078-6013 USA; *Corresponding author: hrokiah@usm.my (R. Hashim)

\section{INTRODUCTION}

Particleboard is one of the most commonly utilized composite panels in the furniture industry; it is produced from wood or non-wood lignocellulosic materials by adding an adhesive and thermally pressing them together to form a flat composite panel. Originally, adhesives that were obtained from animal glue, fresh blood, and casein (which was derived from the milk protein of animals) were used for particleboard production. However, these adhesives had disadvantages, such as instability, low resistance to water, and low bonding strength, thus limiting their usage for the production of particleboard and other wood composites (Conner 2001).

The numerous disadvantages of using animal-derived natural adhesives led to the research and development of synthetic adhesives. Synthetic adhesives, which include ureaformaldehyde (UF), melamine-formaldehyde (MF), and melamine urea-formaldehyde (MUF), have better adhesion properties and provide excellent strength properties to the panels. However, the utilization of formaldehyde-based resins as a synthetic binder in wood-based panels have been considered by the World Health Organization (WHO) as a human carcinogen, which can cause a burning feeling in the eyes, nose, and throat, 
coughing, queasiness, and a reaction in the body in those who use formaldehyde-based resins (Khanjanzadeh et al. 2019). In addition, these synthetic adhesives are derived from natural oil and gas, which are not sustainable. High costs of synthetic adhesives also contribute to a high total cost for the production of particleboards. Therefore, a substantial amount of research on the use of natural materials to produce high quality wood adhesives with comparable characteristics to synthetic adhesives is being performed.

Starch-derived adhesives are one of the two types of binders produced from plants; the other adhesives used are derived from cellulose, lignin, and protein. They have several advantages: they are readily available, generally have a low cost, have a stable quality, are nontoxic, are readily biodegradable, have a high heat resistance, and are insoluble in oil and fats (Ferdosian et al. 2017).

However, due to the presence of hydrogen bonds among the starch molecules, the morphology of starch is the combination of unsteady amorphous regions in very crystal regions. Therefore, the penetration of water and chemical components into the structure is inhibited by the crystalline regions, which leads to an increased gelation temperature and decreased reactivity of the starch. Thus, it has been suggested that adjustments need to be made to reduce the crystallinity of the starch region (Zhang et al. 2015).

Crosslinking is frequently employed to modify starch. The mechanical stability of starch is improved by adding intramolecular bonds to the structure of the starch molecules, which results in the enhancement of the functional properties of the starch (Acquarone and Rao 2003). The crosslinking reaction also affects the physical, chemical, and thermal characteristics of the starch (Gonenc and Us 2019).

The crosslinking of citric acid and starch is attributed to the carboxyl and hydroxyl groups present in the reaction; citric acid possesses carboxyl groups that react with the hydroxyl groups from the starch. These carboxyl groups are ester-linked with the hydroxyl groups present in the fibrous material and are the primary influence causing the improved dimensional stability. Starch is more reactive to the citric acid than the fiber used in making the panel (Widyorini et al. 2017). Glutardialdehyde is a clear, organic compound with a chemical formula of $\mathrm{CH}_{2}\left(\mathrm{CH}_{2} \mathrm{CHO}\right)_{2}$ and is an efficient starch crosslinker (Amini et al. 2015; Akinyemi et al. 2019). Starch crosslinking with glutardialdehyde is generally achieved via a reaction that takes place by substituting a hydroxyl group with a carboxyl group to form hemiacetal links (Gonenc and Us 2019).

The functional groups synthesized during the starch modification process would improve the use of the adhesives for wood composite applications. Currently, minimal research has been done using coconut fibers as an alternative to wood for the production of particleboards (Verma et al. 2013). There is also little information on the use of citric acid or glutardialdehyde to modify potato starch as a binder for particleboards manufactured from coconut fibers. Therefore, the objective of this study was to evaluate the basic properties and mechanical properties of experimental particleboard panels manufactured using coconut fiber.

\section{EXPERIMENTAL}

\section{Preparation of the Coconut Fibers}

The coconut fibers were obtained from a mill in Sungai Besar, Selangor, Malaysia. First, the coconut fibers were air-dried, to remove the coconut husk, the pith, metals, stones, and other impurities. It was then further dried with an oven to reduce the moisture content 
to $5 \%$ before being used for particleboard production.

\section{Chemical Characterization of the Coconut Fibers}

The chemical analysis was performed according to methods reported by the Technical Association of Pulp and Paper Industry (TAPPI). To enable complete reactions of the fibre samples with the chemicals during chemical analysis, the samples were ground to pass through a $0.4 \mathrm{~mm}$ mesh sieve (Lamaming et al. 2013). Before further chemical analysis, the coconut fiber was oven-dried and underwent an ethanol-benzene extraction, according to TAPPI standard T $204 \mathrm{~cm}$ (2017), to ensure no extractives remained. The ash content, the Klason lignin content, the $\alpha$-cellulose content, and the $1 \% \mathrm{NaOH}$ solubility were evaluated according to TAPPI T-211 om (1993), TAPPI T-222 om (2002), T-203 cm (1999), and T-212 om (2002), respectively. The methodology described by Wise and Karl (1962) was also used to evaluate the holocellulose content of the raw material.

\section{Preparation of the Adhesives}

The materials used for the production of the adhesive were analytical grade; the potato starch was procured from Sigma-Aldrich (St. Louis, MO), the citric acid was produced by R\&M Chemicals (Tamil Nadu, India), and the glutardialdehyde was supplied by Merck Chemical Company (Darmstadt, Germany).

Native commercial potato starch was added to distilled water to form a slurry and was stirred at room temperature for $30 \mathrm{~min}$ in order to form the adhesive used for the production of particleboards.

Citric acid was used to modify the potato starch, with a slight modification to the method used by Widyorini et al. (2017). The citric acid and potato starch were dissolved in $60 \mathrm{~mL}$ of hot distilled water $\left(70{ }^{\circ} \mathrm{C} \pm 2{ }^{\circ} \mathrm{C}\right)$. Adhesive contents of 10 to $15 \%$ of the ovendried particle weight were prepared with a mixture ratio of citric acid to starch were 75 to $25(\mathrm{w} / \mathrm{w})$, which was the optimum mixture ratio for the best particleboard properties (Widyorini et al. 2017).

The potato starch was modified according to the method described by Amini et al. (2019). The potato starch in powder form was modified with glutardialdehyde in liquid form at a ratio of 1 to 2 (w/w). This was accomplished by dissolving the starch powder in $60 \mathrm{~mL}$ of distilled water at $30{ }^{\circ} \mathrm{C}$, and then the mixture was heated up to $50{ }^{\circ} \mathrm{C}$ before a $25 \%$ glutardialdehyde solution was added and further heated to $60{ }^{\circ} \mathrm{C}$.

\section{Particleboard Manufacturing}

The coconut fibers were dried to a moisture content of 5\% in a laboratory-type oven (Ecocell). The moisture content was checked at interval using a Mettler Toledo HE73 moisture analyzer until it reached $5 \%$. Three different amount of adhesives were used for the panels $(10 \%, 12 \%$, and $15 \%)$, which were based on the oven-dry particle weight. The adhesives used were the potato starch, the citric acid-modified potato starch and the glutardialdehyde-modified potato starch. A total of 45 experimental panels, 5 for each adhesive and percentage combination were manufactured. A binderless panel was also manufactured for analysis as a control panel, which was produced without the addition of an adhesive.

The raw materials for each combination were manually mixed with the adhesive to be as homogenous as possible before a $20.5 \mathrm{~cm}$ by $20.5 \mathrm{~cm}$ mat was formed using a rectangular mold. Each mat was compressed in an automated press machine at a pressure of $150 \mathrm{~kg} / \mathrm{cm}^{2}$ and at a temperature of $145^{\circ} \mathrm{C}$ for $20 \mathrm{~min}$. A thick steel bar of $0.5 \mathrm{~cm}$ was 
used to control the particleboard thickness during the hot-pressing, while the target density was set to $0.80 \mathrm{~g} / \mathrm{cm}^{3}$. The compressed panels were trimmed and kept in a conditioning room with a relative humidity of $65 \%$ and a temperature of $25{ }^{\circ} \mathrm{C}$ for two weeks before cutting into test specimens (Sulaiman et al. 2012).

\section{Characterization of the Particleboards}

Physical properties of the samples

The physical properties of the samples, which included the density, thickness swelling (TS), and water absorption (WA), were evaluated according to JIS standard A5908 (2003). The dimensions and weight of each sample were determined at accuracy levels of $0.01 \mathrm{~mm}$ and $0.01 \mathrm{~g}$, respectively. Both the TS and the WA of the panel samples were evaluated by soaking the samples in distilled water for $2 \mathrm{~h}$ and $24 \mathrm{~h}$, respectively.

\section{Mechanical Properties of the Samples}

The modulus of elasticity (MOE), modulus of rupture (MOR), and internal bonding strength (IB) of the samples were determined according to JIS standard A-5908 (2003). For the MOR and MOE tests, $5 \mathrm{~cm}$ by $20 \mathrm{~cm}$ samples were cut from each panel and $5 \mathrm{~cm}$ by $5 \mathrm{~cm}$ samples were cut for the analysis of the internal bonding strength. A universal testing machine (Model 5582, Instron, Norwood, MA) was employed to perform the two mechanical tests using a crosshead speed of $10 \mathrm{~mm} / \mathrm{min}$ for the bending tests and a crosshead speed of $2 \mathrm{~mm} / \mathrm{min}$ for the internal bond strength test.

\section{Vertical Density Profile (VDP) Analysis}

The variation in the density gradient profile of the experimental panels through the direction of the thickness was determined via VDP analysis. In this study, the VDP test was done on only the particleboard samples produced with $15 \%$ adhesive content; this was due to the good physical and mechanical properties exhibited. The readings were taken based on the average of three replicates. This analysis was done with a GreCon X-ray densitometry system (Model DA-X, Hannover, Germany). The $50 \mathrm{~mm}$ by $50 \mathrm{~mm}$ sample was placed in the sample holder, and as the profile reading began, the density reading was shown on a computer screen (Hunt et al. 2017).

\section{Fourier Transform-infrared (FTIR) Spectroscopy}

Small amounts of samples were prepared from each panels by grinding them into powder using a grinding machine. About $5 \mathrm{mg}$ of sample was mixed with $95 \mathrm{mg}$ of $\mathrm{KBr}$ and further compressed to form a pellet. The FTIR spectra were measured using an IRPrestige-21 FTIR spectrophotometer (Shimadzu, Kyoto, Japan) from $4000 \mathrm{~cm}^{-1}$ to 400 $\mathrm{cm}^{-1}$, with a resolution of $4.0 \mathrm{~cm}^{-1}$, and 25 total scans were taken (Sulaiman et al. 2018).

\section{X-ray Diffractometry (XRD) Analysis}

The crystallinity of the raw materials in the experimental particleboards were analyzed using a Kristalloflex D-5000 X-ray diffraction system (Siemens, Germany). Cu$\mathrm{K} \alpha \mathrm{X}$-rays were used for the step scan calculations at an opening voltage of $40 \mathrm{kV}$ and a current of $30 \mathrm{~mA}$. A diffraction angle of $2 \theta$, which varied from $10^{\circ}$ to $40^{\circ}$, matched the scanning speed of $0.02^{\circ}$ and $2 \% \mathrm{~min}$. The crystallinity index (CrI) result was calculated using the formula by Segal et al. 1959 as shown in Eq. 1,

$$
\operatorname{CrI}(\%)=\left(\left(I_{002}-I_{\mathrm{am}}\right) / I_{002}\right) \times 100
$$


where $I_{002}$ is the peak intensity corresponding to crystalline and $I_{\mathrm{am}}$ is the peak intensity of the amorphous fraction.

\section{Scanning Electron Microscopy (SEM)}

The samples were cut cross-sectionally and coated with a thin sheet of gold using a Q150 TS SEM coating system (Quorum Technologies, Lewes, United Kingdom) to make them conductive. The microstructure of the board samples was then analyzed using a SEM microscope (Model Quanta FEG 650, FEI Co. Hillsboro, OR) with an acceleration of $5 \mathrm{kV}$ (Sulaiman et al. 2018).

\section{Thermogravimetric Analysis of the Samples}

Thermogravimetric analysis was performed using a Pyris 1 TGA thermogravimeter (Mettler Toledo GmbH, Greifensee, Switzerland) and STARe thermal analysis software (Version 9.20, Mettler Toledo, Columbus, $\mathrm{OH}$ ) to determine the thermal decomposition of the samples. The powdered specimen ( $5 \mathrm{mg}$ to $10 \mathrm{mg}$ ) was placed in an aluminum pan; the values were recorded at a temperature range between $30{ }^{\circ} \mathrm{C}$ and $800{ }^{\circ} \mathrm{C}$, with a heating rate of $10^{\circ} \mathrm{C} / \mathrm{min}$ under a nitrogen atmosphere (Sulaiman et al. 2012).

\section{RESULTS AND DISCUSSION}

\section{Chemical Analysis of the Coconut Fiber}

Lignin, holocellulose, and the extractive contents are the major constituents of lignocellulosic materials (Ashori et al. 2011). The results from the evaluation of the chemical analysis of the coconut fiber are displayed in Table 1. It appeared that the coconut fiber had a high lignin content (62.9\%) and was comparable to the value of the lignin content (59.4\%) determined by Jústiz-Smith et al. (2008). The high lignin content of the coconut fiber will aid in the bonding of the particleboard as it melts to the surface when heat and pressure are applied; therefore, the lignin in the fiber improved the binding quality of the fibers (Ashori et al. 2011).

The extractive content of the sample was determined to be $9.0 \%$. The slightly darker color of the fiber was the result of its high extractives content. The coconut fiber after undergoing complete combustion in the furnace yielded an ash content of $2.9 \%$, which was comparable to the ash content in a past study (2.2\%) carried out by Verma et al. (2013).

Table 1. Chemical Analysis of the Coconut Fiber

\begin{tabular}{|c|c|}
\hline Analysis & $(\%)$ \\
\hline Ash Content & $2.9(0.1)$ \\
\hline Extractive Content & $9.0(0.6)$ \\
\hline Klason Lignin Content & $62.9(3.4)$ \\
\hline Holocellulose & $65.9(0.8)$ \\
\hline Hot Water Solubility & $11.0(1.3)$ \\
\hline Alkaline Solubility (1\% NaOH) & $70.8(1.5)$ \\
\hline Alpha-Cellulose & $46.1(2.1)$ \\
\hline Numbers in parentheses are the standard deviation values \\
\hline
\end{tabular}


The holocellulose content had a higher value (65.9\%), when compared to the results from Tsoumis (1991), which had a holocellulose content of 56.3\%. A high value $(46.1 \%)$ was obtained for the alpha-cellulose content, which indicated that the coconut fiber should provide greater strength due to its high $\alpha$-cellulose content, as it aids the strength of the cell walls (Ashori et al. 2011). It was comparable with the results obtained by Verma et al. (2013), with an $\alpha$-cellulose content value of $43.4 \%$. The results in this study supported the usage of coconut fiber as a potential wood alternative for particleboard application. It is worthy of mention that the chemical analysis of the fiber was carried out independently, thus, not totaling up to $100 \%$.

\section{Physical Properties of the Samples}

Table 2 showed the thickness swelling (TS) and water absorption (WA) properties of all particleboards. The TS and WA ranged from $10.8 \%$ and $37.9 \%$, respectively, for the sample bonded with $15 \%$ citric acid-modified potato starch to $34.0 \%$ and $98.1 \%$, respectively, for the $15 \%$ native potato starch bonded samples. According to JIS standard A-5908 (2003), the maximum value allowed for thickness swelling is $12 \%$. Thus, the particleboards with a TS greater than $12 \%$ did not meet the standard; hence, it was suggested that water-resistant adhesives should be added to the compositions to improve their dimensional stability.

Table 2. Physical and Mechanical Properties of the Particleboards Produced with Adhesives Formulations

\begin{tabular}{|c|c|c|c|c|c|c|c|c|}
\hline $\begin{array}{c}\text { Adhesive } \\
\text { Type }\end{array}$ & $\begin{array}{c}\text { Percentage } \\
\text { Formulation } \\
\text { (\%) }\end{array}$ & $\begin{array}{l}\text { TS } \\
2 \mathrm{~h} \\
(\%)\end{array}$ & $\begin{array}{l}24 \mathrm{~h} \\
(\%)\end{array}$ & $\begin{array}{l}\text { WA } \\
2 \mathrm{~h} \\
(\%)\end{array}$ & $\begin{array}{c}24 \mathrm{~h} \\
(\%)\end{array}$ & $\begin{array}{c}\mathrm{MOE} \\
\left(\mathrm{N} / \mathrm{mm}^{2}\right)\end{array}$ & $\begin{array}{c}\mathrm{MOR} \\
\left(\mathrm{N} / \mathrm{mm}^{2}\right)\end{array}$ & $\begin{array}{c}\text { IB } \\
\left(\mathrm{N} / \mathrm{mm}^{2}\right)\end{array}$ \\
\hline \multirow{3}{*}{$\begin{array}{c}\text { NPS } \\
\text { (Control) }\end{array}$} & 10 & $\begin{array}{l}19.8 \\
(0.3) \\
\end{array}$ & $\begin{array}{l}28.8 \\
(0.6) \\
\end{array}$ & $\begin{array}{l}60.9 \\
(2.0) \\
\end{array}$ & $\begin{array}{l}90.0 \\
(3.3) \\
\end{array}$ & $\begin{array}{c}1072.0 \\
(92.5) \\
\end{array}$ & $\begin{array}{l}20.8 \\
(1.2) \\
\end{array}$ & $\begin{array}{c}0.16 \\
(0.03) \\
\end{array}$ \\
\hline & 12 & $\begin{array}{l}21.4 \\
(0.81\end{array}$ & $\begin{array}{l}30.9 \\
(0.8)\end{array}$ & $\begin{array}{l}47.2 \\
(1.8)\end{array}$ & $\begin{array}{l}79.1 \\
(3.6)\end{array}$ & $\begin{array}{c}1024.0 \\
(64.0)\end{array}$ & $\begin{array}{l}23.9 \\
(1.2)\end{array}$ & $\begin{array}{c}0.28 \\
(0.03)\end{array}$ \\
\hline & 15 & $\begin{array}{l}25.6 \\
(1.1) \\
\end{array}$ & $\begin{array}{l}34.0 \\
(0.9) \\
\end{array}$ & $\begin{array}{l}58.8 \\
(1.2) \\
\end{array}$ & $\begin{array}{l}98.1 \\
(3.6) \\
\end{array}$ & $\begin{array}{c}1315.0 \\
(65.2) \\
\end{array}$ & $\begin{array}{l}22.2 \\
(1.5) \\
\end{array}$ & $\begin{array}{c}0.4 \\
(0.03) \\
\end{array}$ \\
\hline \multirow{3}{*}{ CAMPS } & 10 & $\begin{array}{c}4.3 \\
(0.6)\end{array}$ & $\begin{array}{l}15.6 \\
(0.7)\end{array}$ & $\begin{array}{l}22.2 \\
(1.1)\end{array}$ & $\begin{array}{l}44.7 \\
(1.9)\end{array}$ & $\begin{array}{l}2478.6 \\
(134.3) \\
\end{array}$ & $\begin{array}{l}21.2 \\
(0.9)\end{array}$ & $\begin{array}{c}0.75 \\
(0.06)\end{array}$ \\
\hline & 12 & $\begin{array}{c}4.9 \\
(0.5)\end{array}$ & $\begin{array}{l}11.7 \\
(0.8)\end{array}$ & $\begin{array}{l}20.9 \\
(1.0)\end{array}$ & $\begin{array}{l}44.2 \\
(3.7)\end{array}$ & $\begin{array}{l}3027.6 \\
(158.5)\end{array}$ & $\begin{array}{l}22.3 \\
(1.2)\end{array}$ & $\begin{array}{c}1.21 \\
(0.06)\end{array}$ \\
\hline & 15 & $\begin{array}{c}4.2 \\
(0.15)\end{array}$ & $\begin{array}{l}10.8 \\
(0.2)\end{array}$ & $\begin{array}{l}18.4 \\
(0.6)\end{array}$ & $\begin{array}{l}37.9 \\
(2.0)\end{array}$ & $\begin{array}{l}3180.1 \\
(129.2)\end{array}$ & $\begin{array}{l}23.7 \\
(1.9)\end{array}$ & $\begin{array}{c}1.48 \\
(0.04)\end{array}$ \\
\hline \multirow{3}{*}{ GMPS } & 10 & $\begin{array}{l}15.0 \\
(0.5)\end{array}$ & $\begin{array}{l}31.2 \\
(1.1)\end{array}$ & $\begin{array}{l}52.2 \\
(1.8)\end{array}$ & $\begin{array}{l}88.5 \\
(4.8)\end{array}$ & $\begin{array}{l}1648.2 \\
(107.1)\end{array}$ & $\begin{array}{l}22.2 \\
(1.0)\end{array}$ & $\begin{array}{c}0.33 \\
(0.03)\end{array}$ \\
\hline & 12 & $\begin{array}{l}13.4 \\
(0.5)\end{array}$ & $\begin{array}{l}22.2 \\
(1.1)\end{array}$ & $\begin{array}{l}44.7 \\
(2.6)\end{array}$ & $\begin{array}{l}74.8 \\
(4.7)\end{array}$ & $\begin{array}{c}2035.0 \\
(71.4)\end{array}$ & $\begin{array}{l}32.8 \\
(1.3)\end{array}$ & $\begin{array}{c}0.74 \\
(0.04)\end{array}$ \\
\hline & 15 & $\begin{array}{l}18.4 \\
(0.5)\end{array}$ & $\begin{array}{l}26.6 \\
(1.1)\end{array}$ & $\begin{array}{l}45.5 \\
(2.3)\end{array}$ & $\begin{array}{l}81.2 \\
(2.6)\end{array}$ & $\begin{array}{c}2157.9 \\
(81.0)\end{array}$ & $\begin{array}{l}26.9 \\
(0.8)\end{array}$ & $\begin{array}{c}0.45 \\
(0.05)\end{array}$ \\
\hline
\end{tabular}

Data is expressed as the average and the values in parentheses are the standard deviations NPS: native potato starch, CAMPS: citric acid-modified potato starch, GMPS:

glutardialdehyde-modified potato starch, TS: thickness swelling, WA: water absorption, MOE:

modulus of elasticity, MOR: modulus of rupture, IB: internal bonding strength 
Generally, the CAMPS adhesive-bonded particleboards yielded the highest values for the physical properties. In addition, it met the requirements for the physical properties according to JIS standard A-5908 (2003). For the GMPS adhesive, the WA and TS could be improved via the addition of one of the numerous types of additives that could serve as a water repellant in the particleboard manufacturing process (Sulaiman et al. 2012). Other pretreatments could also be tried on the coconut fiber before being used for the production of the panels.

\section{Mechanical Properties of the Particleboards}

Table 2 shows the average values of the modulus of rupture (MOR), modulus of elasticity (MOE), and the IB strength evaluated according to JIS standard A-5908 (2003). For the MOR, all of the panels produced with the test adhesives exceeded the JIS standard minimum requirement for Type 18 particleboards $\left(18 \mathrm{~N} / \mathrm{mm}^{2}\right)$ (JIS-A-5908 2003). For the NPS panels, the highest MOE, MOR, and IB values were $1315 \mathrm{~N} / \mathrm{mm}^{2}, 23.9 \mathrm{~N} / \mathrm{mm}^{2}$, and $0.40 \mathrm{~N} / \mathrm{mm}^{2}$, respectively. However, none of the panels produced with an NPS adhesive met the JIS standard for the MOE, since the minimum requirement for Type 8 particleboards is $2000 \mathrm{~N} / \mathrm{mm}^{2}$ (JIS-A-5908 2003). The internal bonding (IB) strength of the NPS particleboards increased as the formulation percentage increased. Although the $10 \%$ NPS particleboard yielded a low IB value $\left(0.16 \mathrm{~N} / \mathrm{mm}^{2}\right)$, it was still able to meet the minimum requirement for Type 8 particleboards $\left(0.15 \mathrm{~N} / \mathrm{mm}^{2}\right)$.

For the particleboards bonded with a CAMPS adhesive, as indicated in Table 2, the mechanical strength increased with an increase in the adhesive percentage. The $15 \%$ CAMPS adhesive yielded the highest mechanical strength $\left(3180 \mathrm{~N} / \mathrm{mm}^{2}, 23.68 \mathrm{~N} / \mathrm{mm}^{2}\right.$, and $1.48 \mathrm{~N} / \mathrm{mm}^{2}$ ), which met the minimum requirements for Type 18 particleboards. This improvement in the mechanical strength could be attributed to the addition of citric acid, which supported improved bonding between the starch particles and the coconut fiber.

The GMPS particleboards had the same trend as the NPS particleboards, as the $15 \%$ GMPS yielded the highest MOE value $\left(2158 \mathrm{~N} / \mathrm{mm}^{2}\right)$, which was comparable to Type 8 particleboard; while the 12\% GMPS particleboards yielded the highest MOR and IB values $\left(32.81 \mathrm{~N} / \mathrm{mm}^{2}\right.$ and $0.74 \mathrm{~N} / \mathrm{mm}^{2}$, respectively). Thus, it could be deduced that the optimum percentage formulation for GMPS particleboards was $12 \%$.

Panels bonded with the CAMPS adhesive yielded the highest overall mechanical strength values, with the GMPS and the NPS adhesives following in second and third highest overall mechanical strength values, respectively. All of the modified starch adhesives met the minimum mechanical strength requirements, except for the $10 \%$ GMPS adhesive particleboard, which had a low MOE value. These results were in line with the results from Amini et al. (2013) and Widyorini et al. (2017).

\section{Vertical Density Profile (VDP) of The Experimental Panel}

The VDP of the particleboard is the most important parameter in terms of both the mechanical and physical properties of the panel. This property was analyzed to observe the density changes of the panel through its thickness direction. All of the graphs of the panel samples exhibited a flat density gradient. The NPS density gradient had a flatter density gradient than the other two particleboard samples. The external surfaces of the panels displayed a higher peak density; the density was shown to gradually decrease as the analysis continued in its thickness direction, up to the central region, and was essentially flat at the core. The profile gradients shown in Fig. 1 were attributed to the manufacturing process, when heat and pressure were applied to the formed mat; the fiber particles and 
adhesive melted and plasticized together with the aid of the increased temperature and moisture content present in the mix. The steam generated by the moisture heated the central region of the experimental panel, and the rest of the steam evaporated (Hunt et al. 2017).

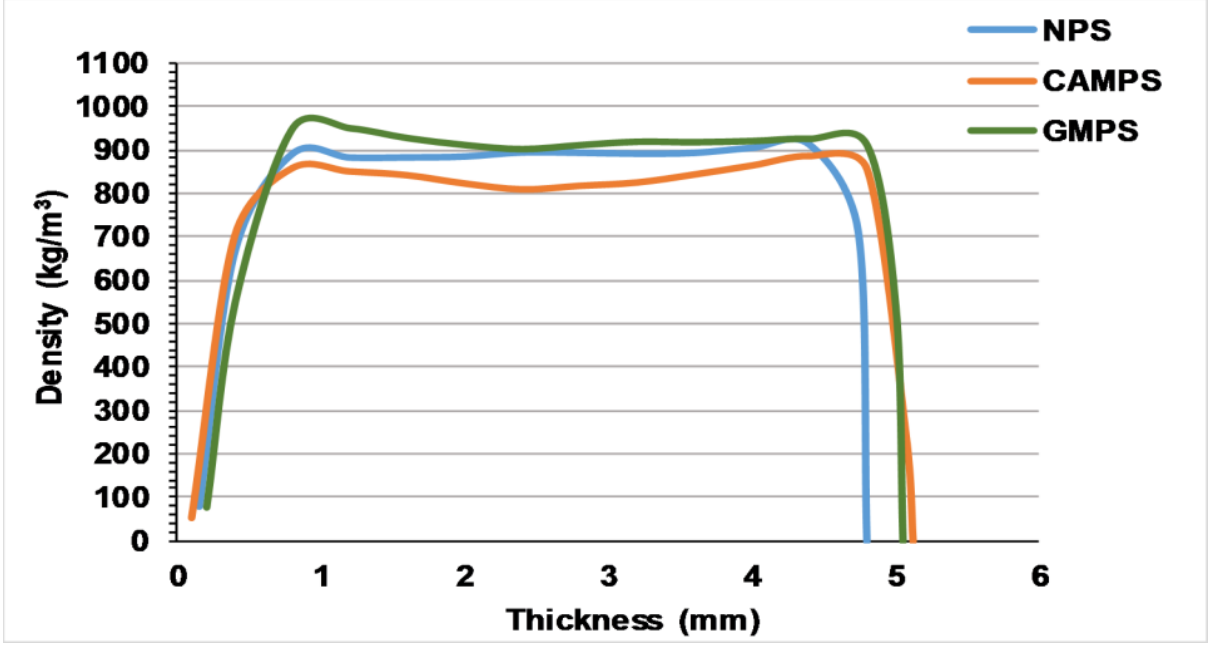

Fig. 1. The vertical density profile of the native potato starch (NPS), citric acid modified potato starch (CAMPS), and glutardialdehyde modified potato starch (GMPS) particleboard samples.

(a)

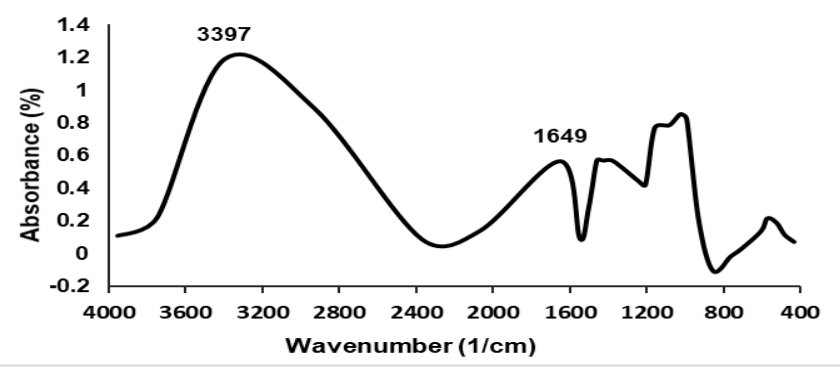

(b)

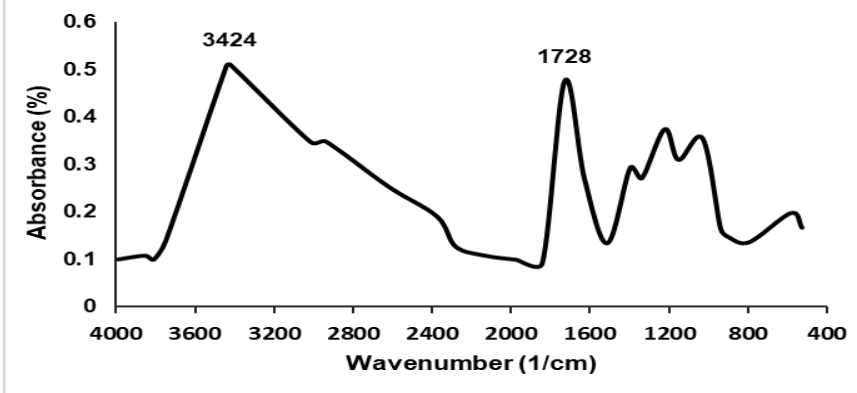

(c)

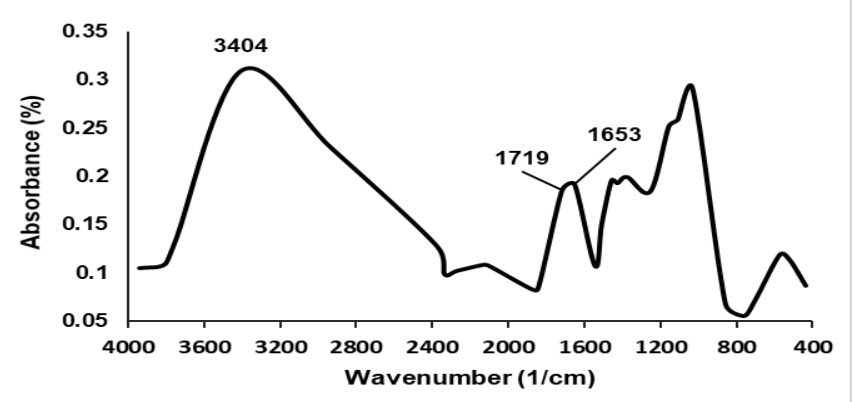

Fig. 2. The FT-IR for the powdered particleboard samples produced with (a) native potato starch (NPS), (b) citric acid modified potato starch (CAMPS), and (c) glutardialdehyde modified potato starch (GMPS) adhesives. 


\section{Fourier Transform-infrared spectroscopy (FT-IR) Analysis}

The FT-IR spectra determined the functional groups present in the different particleboards, and Fig. 2 presents the bands obtained from the analysis. The NPS sample showed an absorption peak at $3397 \mathrm{~cm}^{-1}$, which corresponded to O-H stretching (hydroxyl group) and the NPS starch had enough hydroxyl groups to attach to the hydroxyl group present in the coconut fiber.

The CAMPS spectra displayed absorption peaks at $3435 \mathrm{~cm}^{-1}$ and at $1728 \mathrm{~cm}^{-1}$, which corresponded to $\mathrm{O}-\mathrm{H}$ stretching (hydroxyl group) and $\mathrm{C}=\mathrm{O}$ stretching (carboxyl group), respectively. The carboxyl group indicated the presence of citric acid, and the hydroxyl group in the starch should crosslink with the hydroxyl group in the citric acid, which should aid in attachment to the fiber (Reddy and Yang 2010). Absorption peaks at $3404 \mathrm{~cm}^{-1}, 1719 \mathrm{~cm}^{-1}$, and $1653 \mathrm{~cm}^{-1}$ were seen in the GMPS sample spectra, and the peaks represented $\mathrm{O}-\mathrm{H}$ stretching (hydroxyl group), aldehyde $\mathrm{C}=\mathrm{O}$ stretching, and ketone $\mathrm{C}=\mathrm{O}$ stretching. The carbonyl group found in the aldehyde and ketone forms indicated the presence of GMPS in the sample, while it attached to the hydroxyl group (Amini et al. 2013; Akinyemi et al. 2019). This analysis provided evidence into the modification of potato starch in order to produce better adhesives.

\section{Thermogravimetric Analysis (TGA) of the Samples}

The TGA analysis of the samples evaluated their thermal stability by measuring the mass of the sample as it underwent thermal changes. Figures $3 \mathrm{a}$ and $3 \mathrm{~b}$ illustrate the weight loss (\%) curves (TG) and the derivative thermogravimetric (DTGA) curves of the samples, respectively.

(a)

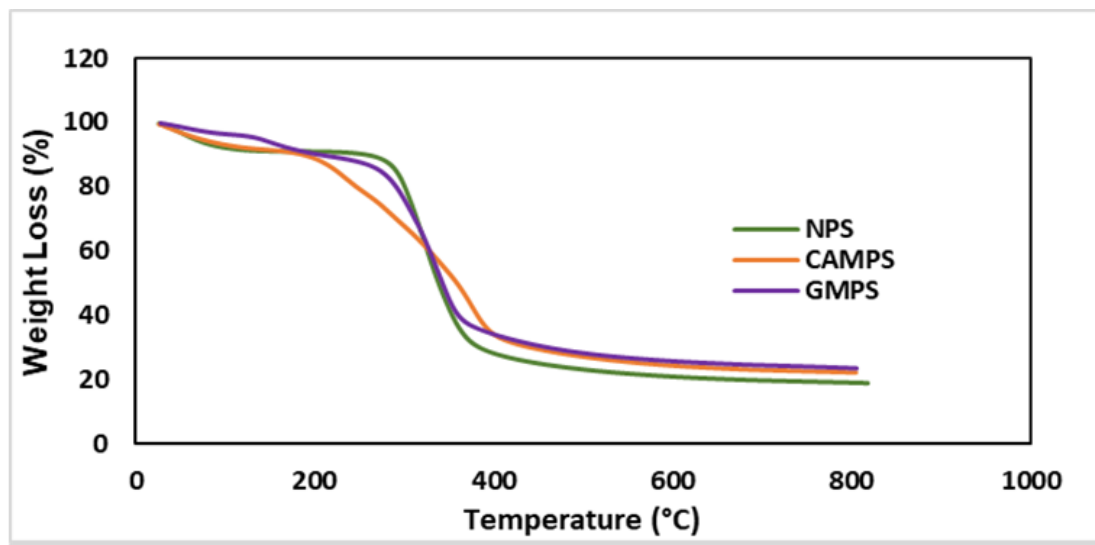

(b)

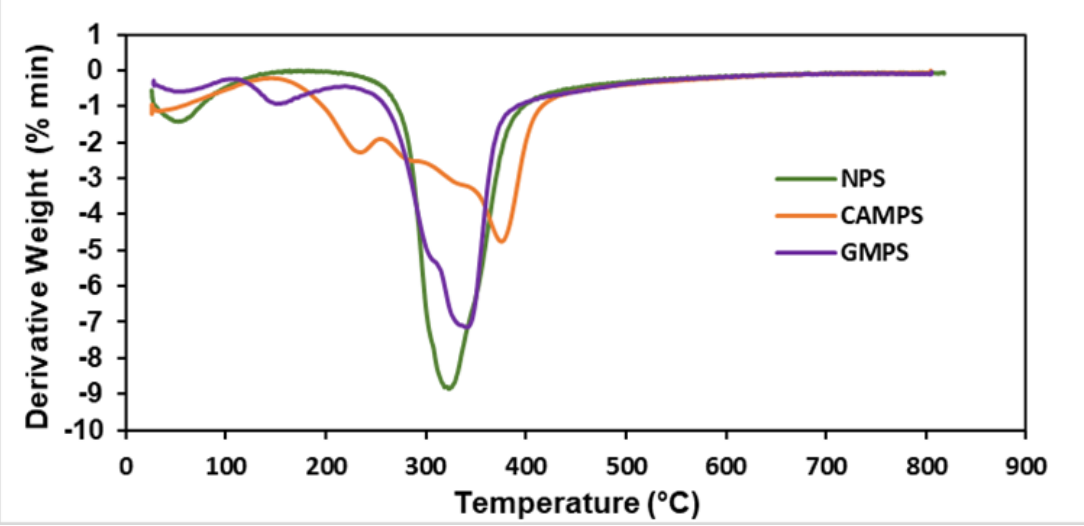

Fig. 3. TGA and DTG curves of samples bonded with: native potato starch (NPS), citric acid modified potato starch (CAMPS), and glutardialdehyde modified potato starch (GMPS) adhesives 
All the samples showed weight loss at the initial stage, due to the evaporation of water and the decomposition of unstable materials, hemicellulose, and carbon dioxide, at a temperature range of $30{ }^{\circ} \mathrm{C}$ to $100{ }^{\circ} \mathrm{C}$ (Sulaiman et al. 2012). Samples that bonded with NPS decomposed from approximately $60{ }^{\circ} \mathrm{C}$ to $164{ }^{\circ} \mathrm{C}$. The weight decreased from $96 \%$ to $91 \%$, which also occurred in the samples manufactured with CAMPS, which had a degradation range between $147^{\circ} \mathrm{C}$ and $235^{\circ} \mathrm{C}$; this might be due to the depolymerization of starch in acidic conditions with lower degradation temperatures (Wang et al. 2007). The samples produced with GMPS adhesives decomposed at $155^{\circ} \mathrm{C}$ to $212^{\circ} \mathrm{C}$, and their weight loss or decomposition could due to the degradation of the adhesive in the samples. The DTG profile of the curves (shown in Fig. 3b) depicted a more detailed interpretation of the analysis; the fast degradation occurred at $319^{\circ} \mathrm{C}, 376^{\circ} \mathrm{C}$, and $340{ }^{\circ} \mathrm{C}$ for the NPS, CAMPS, and GMPS particleboards, respectively. The experiment ended at $800{ }^{\circ} \mathrm{C}$ with a resulting residue weight of $19 \%$ for NPS, $22 \%$ for CAMPS, and $24 \%$ for GMPS, which had the highest residue of the particleboard samples.

\section{Scanning Electron Microscopy (SEM) Analysis of the Samples}

The micro-images of the cross-sectional area of the panels are presented in Figs. 4a through $4 \mathrm{~d}$, and were observed via SEM analysis. These micrographs showed the compaction and the effects of the different adhesives as a binder. The control particleboard was made without an adhesive and was evaluated in order to compare the appearance of coconut fiber panels made with and without an adhesive. As shown in Fig. 4a, the fiber had multiple open pores and spaces, which indicated low compaction.
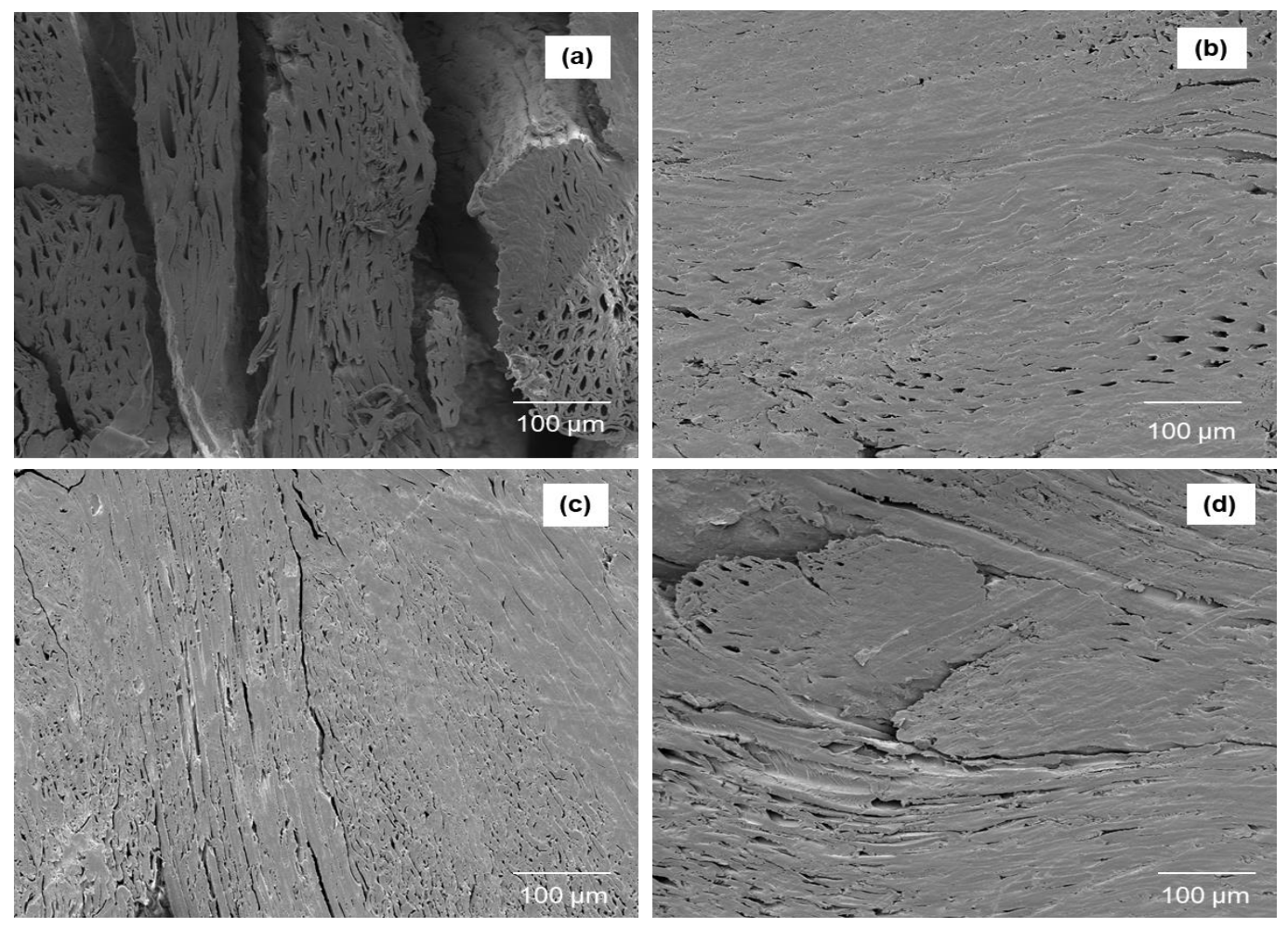

Fig. 4. SEM micrographs (1000x magnification) showing a cross section view of the samples (a) Control (binderless) particleboard (b) native potato starch (NPS), (c) citric acid modified potato starch (CAMPS), and (d) glutardialdehyde modified potato starch (GMPS) particleboard 
In Fig. 4b, the SEM images of the NPS particleboard were observed to have fewer open voids and a closer compact structure between the fibers; this evaluation showed that the starch granules melted and filled into the open pores, thus reducing the size of the pores and increasing the compactness of the panels. Figure 4c, which showed the CAMPS bonded panels, was shown to have a noticeable level of compactness and filled pore space. The compressed cell walls of the fibers had a compacted structure due to the manufacturing pressure, which was aided by the modified adhesive that was rooted and well dispersed among the fiber particles.

The SEM analysis for the GMPS bonded boards (shown in Fig. 4d) indicated the presence of the modified starch adhesive, as there was strong bonding between the adhesive and the fibers. The adhesive lodged into the pores and aided compaction of the panels; which improved the properties of the particleboards. The factor that immensely contributed to the improvement of the dimensional stability and the physical and mechanical properties was the starch granules occupying the spaces between the particle surfaces. When the heat was applied, the modified starches were gelatinized which the granules broke and swell, releasing the entangled amylopectin (Akinyemi et al. 2019). This evaluation was also supported by the physical and mechanical properties of the various boards, where it was shown that the modified starches produced better particleboards.

\section{XRD Analysis}

The crystallinity index of the coconut fiber and the experimental panels were evaluated using XRD analysis, and Fig. 5 shows the X-ray patterns of the samples.

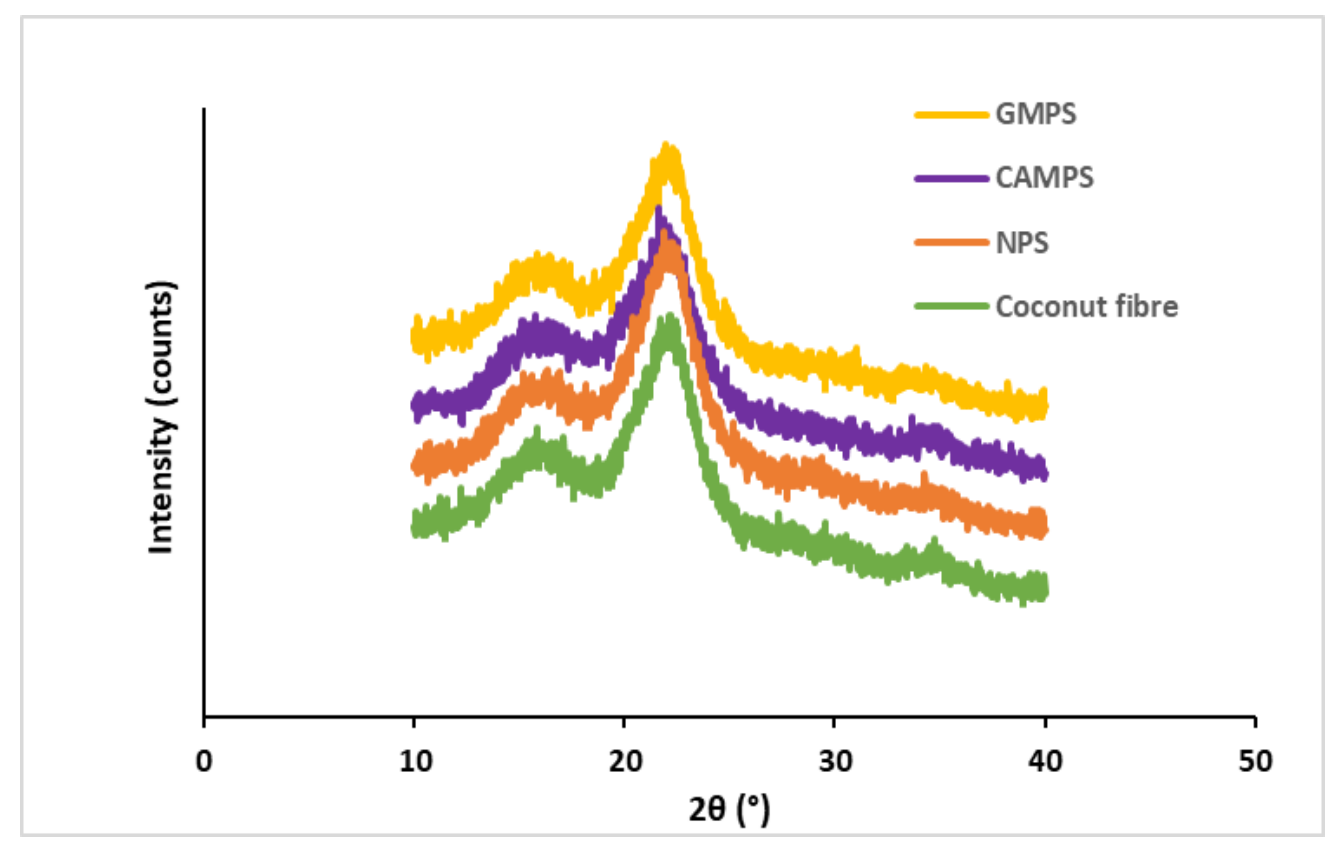

Fig. 5: XRD spectra of coconut fiber, particleboard samples of native potato starch (NPS), citric acid modified potato starch (CAMPS), glutardialdehyde modified potato starch (GMPS) adhesives

The coconut fiber sample, which did not use an adhesive had a crystalline index (CrI) of $42.8 \%$, while the NPS bonded panel had a slightly decreased CrI of $42.0 \%$. However, the samples of panels bonded with a modified adhesive, i.e., CAMPS and GMPS, had a $\mathrm{CrI}$ of $48 \%$ and $44.7 \%$, respectively. Compared to the $\mathrm{CrI}$ of the coconut fiber, the 
panels produced with the modified starch adhesives had a moderately higher CrI; this could be attributed to the higher population of related crystalline regions due to the addition of the modifiers, i.e., citric acid and glutardialdehyde. It was shown that the panels had a moderately low CrI, which indicated the presence of additional amorphous material in the experimental boards, thus, improving the bonding and physical and mechanical properties. The CrI values could be related to the TGA results, in which the samples with a higher $\mathrm{CrI}$ also exhibited greater thermal stability (Sulaiman et al. 2012).

\section{CONCLUSIONS}

1. Samples made with a modified starch resulted in particleboards with enhanced characteristics when compared to those made from a pure native starch.

2. A majority of the panels met the requirements listed in the Japanese industrial standard A-5908 (2003).

3. Based on the SEM, TGA, and FTIR analyses, the overall properties of the samples regarding the binding quality with the fiber, seemed to be enhanced with the usage of modified starch as binder.

4. Coconut fiber, which is considered as a waste material, could have the potential to be used as a raw material in the production of value-added panel products.

5. The results indicate that the novel production method of manufacturing coconut fiber particleboards with green adhesives, i.e., potato starch, will have a positive impact on the environment.

\section{ACKNOWLEDGEMENTS}

The authors would like to acknowledge Universiti Sains Malaysia for providing research financing and support to Amina Adedoja Owodunni through a Research University Grant (1001/PTEKIND/8014083).

\section{REFERENCES CITED}

Acquarone, V. M., and Rao, M. A. (2003). "Influence of sucrose on the rheology and granule size of cross-linked waxy maize starch dispersions heated at two temperatures," Carbohydrate Polymers 51(4), 451-458. DOI: 10.1016/S01448617(02)00217-5

Akinyemi, B. A., Olamide, O., and Oluwasogo, D. (2019). "Formaldehyde free particleboards from wood chip wastes using glutaraldehyde modified cassava starch as binder," Case Studies in Construction Materials 11, 1-8. DOI: 10.1016/j.cscm.2019.e00236

Amini, M. H. M., Hashim, R., and Sulaiman, N. S. (2019). "Formaldehyde-free wood composite fabricated using oil palm starch modified with glutardialdehyde as the binder," International Journal of Chemical Engineering 2019, 1-9. DOI: $10.1155 / 2019 / 5357890$ 
Amini, M. H. M., Hashim, R., Hiziroglu, S., Sulaiman, N. S., and Sulaiman, O. (2013). "Properties of particleboard made from rubberwood using modified starch as binder," Composites Part B: Engineering 50, 259-264. DOI:

10.1016/j.compositesb.2013.02.020

Amini, M. H. M., Hashim, R., Sulaiman, N. S., Hiziroglu, S., Sulaiman, O., Mohamed, M., and Rasat, M. M. S. (2015). "Glutardialdehyde modified corn starch-urea formaldehyde resin as a binder for particleboard making," Applied Mechanics and Materials 754-755, 89-93. DOI: 10.4028/www.scientific.net/AMM.754-755.89

Ashori, A., Hamzeh, Y., and Amani, F. (2011). "Lemon balm (Melissa officinalis) stalk: Chemical composition and fiber morphology," Journal of Polymers and the Environment 19(1), 297-300. DOI: 10.1007/s10924-010-0279-8

Conner, A. (2001). "Wood: Adhesives," in: Encyclopedia of Materials: Science and Technology, K. H. J. Buschow, R. W. Cahn, M. C. Flemings, B. Ilschner, E. J. Kramer, S. Mahajan, and P. Veyssière (ed.), Elsevier Ltd., Amsterdam, Netherlands.

Ferdosian, F., Pan, Z., Gao, G., and Zhao, B. (2017). "Bio-based adhesives and evaluation for wood composites application," Polymers 9(2), 70-99. DOI: 10.3390/polym 9020070

Gonenc, I., and Us, F. (2019). "Effect of glutaraldehyde crosslinking on degree of substitution, thermal, structural, and physicochemical properties of corn starch," Starch-Stärke, 71(3-4), 1800046

Hunt, J. F., Leng, W., and Tajvidi, M. (2017). "Vertical density profile and internal bond strength of wet-formed particleboard bonded with cellulose nanofibrils," Wood and Fiber Science 49(4), 1-11.

JIS-A-5908. (2003). "Particleboards," Japanese Standard Association, Tokyo, Japan.

Jústiz-Smith, N. G., Virgo, G. J., and Buchanan, V. E. (2008). "Potential of Jamaican banana, coconut coir and bagasse fibers as composite materials," Materials Characterization 59(9), 1273-1278. DOI: 10.1016/j.matchar.2007.10.011

Khanjanzadeh, H., Behrooz, R., Bahramifar, N., Pinkl, S., and Gindl-Altmutter, W. (2019). "Application of surface chemical functionalized cellulose nanocrystals to improve the performance of UF adhesives used in wood based composites - MDF type," Carbohydrate Polymers 206, 11-20. DOI: 10.1016/j.carbpol.2018.10.115

Lamaming, J., Sulaiman, O., Sugimoto, T., Hashim, R., Said, N., and Sato, M. (2013). "Influence of chemical components of oil palm on properties of binderless particleboard," BioResources 8(3), 3358-3371. DOI: 10.15376/biores.8.3.3358-3371

Reddy, N., and Yang, Y. (2010). "Citric acid cross-linking of starch films," Food Chemistry 118(3), 702-711. DOI: 10.1016/j.foodchem.2009.05.050

Segal, L., Creely, J. J., Martin, A. E., and Conrad, C. M. (1959). “An empirical method for estimating the degree of crystallinity of native cellulose using the X-ray diffractometer," Textile Research Journal 29, 786-794. DOI: 10.1177/004051755902901003

Sulaiman, N. S., Hashim, R., Amini, M. H. M., Sulaiman, O., and Hiziroglu, S. (2012). "Evaluation of the properties of particleboard made using oil palm starch modified with epichlorohydrin," BioResources 8(1), 283-301. DOI: 10.15376/biores.8.1.283301

Sulaiman, N. S., Hashim, R., Sulaiman, O., Nasir, M., Amini, M. H. M., and Hiziroglu, S. (2018). "Partial replacement of urea-formaldehyde with modified oil palm starch based adhesive to fabricate particleboard," International Journal of Adhesion and Adhesives 84, 1-8. DOI: 10.1016/j.ijadhadh.2018.02.002 
TAPPI 203 cm-99 (1999). “Alpha-, beta- and gamma-cellulose in pulp,” TAPPI Press, Atlanta, GA.

TAPPI 204 cm-17 (2017). "Solvent extractives of wood and pulp," TAPPI Press, Atlanta, GA.

TAPPI 211 om-93 (1993). “Ash in wood, pulp, paper and paperboard: Combustion at 525 ${ }^{\circ} \mathrm{C}$," TAPPI Press, Atlanta, GA.

TAPPI 212 om-02 (2002). "One percent sodium hydroxide solubility of wood and pulp," TAPPI Press, Atlanta, GA.

TAPPI T-222 (2002). (T 222) “Acid-insoluble lignin in wood and pulp," TAPPI Press, Atlanta, GA.

Tsoumis, G. (1991). Science and Technology of Wood: Structure, Properties, Utilization Van Nostrand Reinhold, New York, NY.

Verma, D., Gope, P. C., Shandilya, A., Gupta, A., and Maheshwari, M. K. (2013). "Coir fiber reinforcement and application in polymer composites," Journal of Material and Environmental Science 4(2), 263-276.

Wang, N., Yu, J., Chang, P. R., and Ma, X. (2007). Influence of Citric Acid on the Properties of Glycerol-plasticized dry Starch (DTPS) and DTPS/Poly (lactic acid) Blends. Starch-Stärke, 59(9), 409-417.

Widyorini, R., Umemura, K., Kusumaningtyas, A. P., and Prayitno, T. A. (2017). "Effect of starch addition on properties of citric acid-bonded particleboard made from bamboo," BioResources 12(4), 8068-8077. DOI: 10.15376/biores.12.4.8068-8077

Wise, L. E., and Karl, H. (1962). Cellulose and Hemicellulose in Pulp and Paper Science and Technology, McGraw Hill, New York.

Zhang, Y., Ding, L., Gu, J., Tan, H., and Zhu, L. (2015). "Preparation and properties of a starch-based wood adhesive with high bonding strength and water resistance," Carbohydrate Polymers 115, 32-37. DOI: 10.1016/j.carbpol.2014.08.063

Article submitted: November 21, 2019; Peer review completed: December 31, 2019; Revised version received: January 15, 2020; Accepted: January 18, 2020; Published: February 7, 2020.

DOI: $10.15376 /$ biores.15.2.2279-2292 